\title{
Service quality evaluation of international freight forwarders: an empirical research in East Asia
}

\author{
Sheng Teng Huang ${ }^{1 *}$, Emrah Bulut ${ }^{2}$ and Okan Duru ${ }^{3}$
}

\author{
* Correspondence: danielhuang@ \\ ntou.edu.tw \\ ${ }^{1}$ Department of Transportation \\ Science, National Taiwan Ocean \\ University, Keelung 20224, Taiwan, \\ Republic of China \\ Full list of author information is \\ available at the end of the article
}

\begin{abstract}
The purpose of this paper is to improve service quality of international freight forwarders and explore practical business solutions to enhance customer service level. Freight forwarder usually acts as an agent to source logistics service for shipper and work closely with carriers such as shipping line and airline companies. This business is characterized by lower capital investment and entry barrier comparing with carriers, and most of their major customers are small or medium size manufactures or traders. Providing high quality service to enhance customer satisfaction is the key mission since competition is extremely severe. This paper empirically investigates the leading freight forwarders to find important customer requirements in East Asian region such as Japan, Korea and Taiwan. Furthermore, the feature of the study by using quality function deployment approach would not only identify key technical measures but also explore meaningful business solutions as direction of quality improvement. The finding reveals key customer requirements are cheaper agency fees, door to door ability and instant response, and the key technical measures are customer relationship management, overall information system, service point and network. We would further discuss the empirical result and conclude managerial meaning for decision makers.
\end{abstract}

Keywords: Quality function deployment, International freight forwarder, Shipping agent, Fuzzy analytic hierarchy process

\section{Introduction}

Global trade is the vigorous force triggering the growth of both regional and world economy. International trade brings a lot of advantages to nations and enterprises to share the fruit of business activities as well as provides people various options to buy their daily necessities. These activities rely on international transportation to connect cargo, people and country to facilitate business growth and regional prosperity. Advance transportation not only provides time utility but also place utility from the point of merchandise production to the point of consumption for the business supply chain management. Governments also make effort to minimize logistics cost through improve infrastructure to overcome the trade barriers and vitalize their manufactures and products to stay competitive in the global market. According to the recent publication of WTO and UNCTAD, over $75 \%$ of the global trade is completed by containerised cargo shipping and the rest of the cargo is mainly dependent on land or air transportation. (WTO, 2013; UNCTAD, 2013) International freight forwarder plays the 
primary role to consolidate containerised cargo from small-medium size and complete business transactions more economically and efficiently. Freight forwarders plays a significant role to complete these economic activities and support small medium-size enterprises with various logistics solution. (Lloyd's List, 2014).

Since financial crisis in 2008, the shipping industry faces serious challenges such as global economic depression and greater market uncertainty. International freight forwarders in East Asian countries also could not immune from these negative effects. To well operate the forwarder business becomes extremely difficult tasks. On the other hand, shippers want better, cheaper, safer, reliable, speedy and professional service since freight forwarder is also important part of their global supply chain management. Customer is getting more demanding and competition from other logistics service provider is getting fierce, so it is necessary for forwarders to redefine standards and strategies to face the changing market and challenges. According to Lloyd's list 2014, top six forwarders in Europe such as DHL Global forwarding and Damco suffer a decline in profit due to fierce competition, currency effects and overcapacity of shipping. Mr. Hanne Sorensen, CEO of Damco, stressed that rather than reducing cost or increasing IT investment, improving overall service quality and productivity may be more useful to enhance profitability. (Lloyd's list, 2014) Therefore, improving the quality of service could not only help the forwarders to survive but also make profits in such brutal shipping market.

The forwarder plays the role as the bridge between carrier and shipper to source various transport solution and earns profits by arranging package of delivery service. As an agent, forwarders tend to have more flexibility to market change since the physical infrastructure investments are far less than the shipping or airline companies. In order to effectively consolidate LCL (Less than container loaded) cargo to containers especially for small medium size manufactures or traders, it is necessary for them to use the service providing by international freight forwarders as intermediary connection to efficiently complete the delivery. In general, the duties of forwarders may include space booking on a ship or aircraft, non-vessel operating carriers (NVOCCs), organizing local and international shipping, providing necessary paperwork and custom clearance, delivery and distribution service, information service, warehousing, consolidation and other related formalities. On the other hand, forwarder's target market is slightly different from carriers since they tend to target on LCL customer for consolidation while liner carriers focus more on attracting FCL (Full container loaded) cargo. In East Asia, market is extremely competitive because service providing by freight forwarder seems to be same or similar to one another, along with the increasing number of new entrants. Thus, competitive advantage of freight forwarders only based on cheaper price is not enough. Enhancing satisfactory customer service becomes strategic and survival issue for forwarders to stay competitive and build sustainability.

Forwarder is a service-oriented industry, and its quality of service is important factor for business success. Service quality is a key issue of managerial goal of business to pursue customer satisfaction. In literature, many scholars already discuss the service quality issues of liner shipping and third party logistics service provider, however, few researches apply quality function deployment (QFD) to explore the service quality requirement of international freight forwarders. The main contribution of this paper is conducting expert consultation from Japan, Korea and Taiwan to define the important solutions for this industry. QFD is a special procedure to transform service quality requirement into technical requirement through analysing the relationship between technical measures and 
customer requirements. Applying QFD would not only identify important service quality requirement but also understand useful technical measure for quality improvement. The basic framework of research process and flowchart are shown in Fig. 1. Figure 1 demonstrate the combining QFD and MCDM technique to define suitable solution for enhancing service quality.

\section{Literature review}

\section{Service attributes of international freight forwarder}

Measuring service quality of freight forwarder industry is not an easy task due to its heterogeneity, intangibility and inseparability. Perceived service quality is the description of interaction between customer and service provider, so we could obtain service quality requirements directly from shipper with quantitative and qualitative surveys. On the other hand, through reviewing literature and practical publication, we could find some researches

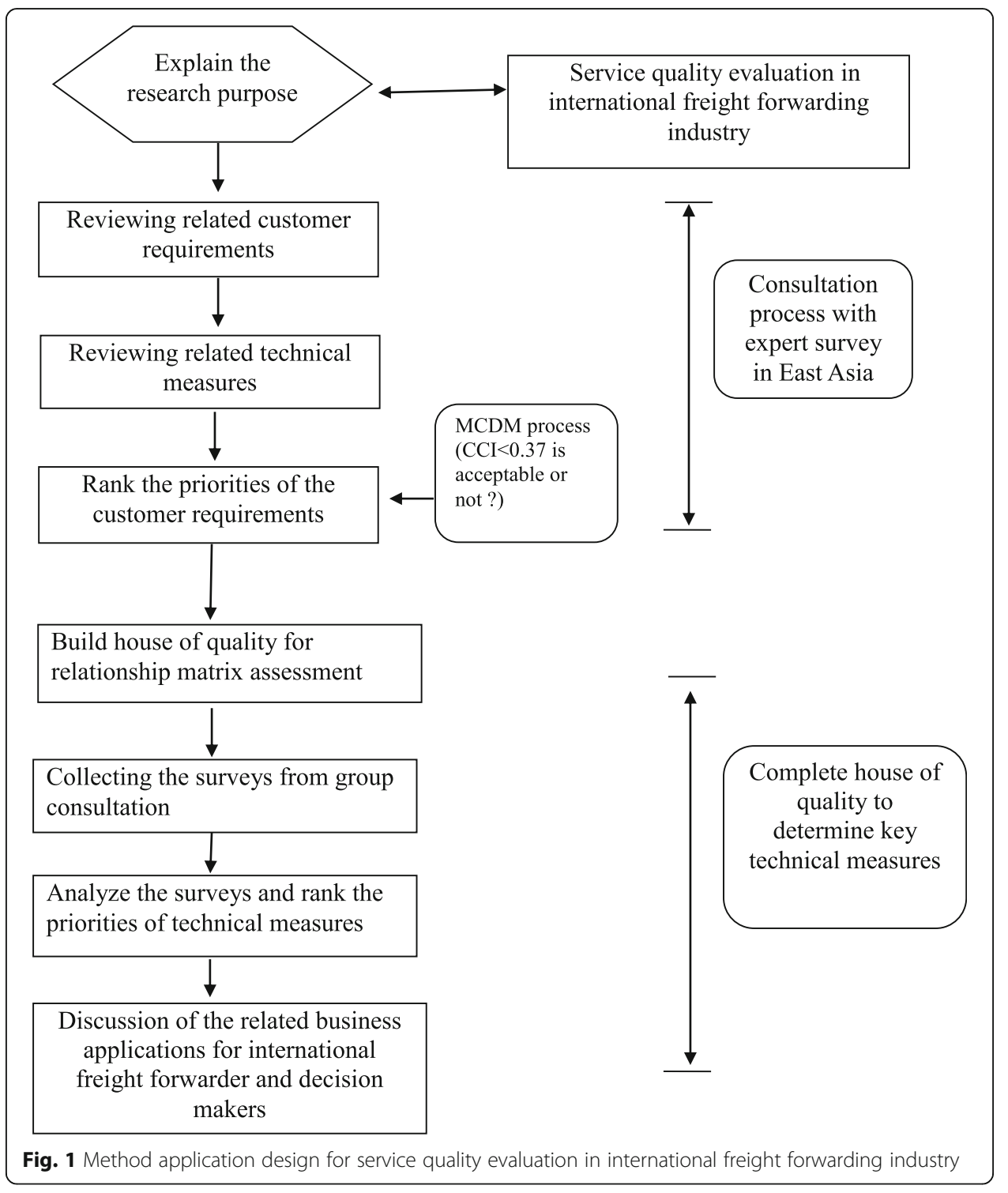


regarding to the service quality requirements of related shipping, logistics or freight forwarding industry. Brooks (1985) reveals the service quality attributes of liner shipping industry such as transit time, directness of sailings, carrier's reputation for reliability, frequency of sailing and next ship leaving. Lu and Dinwoodie (2002) empirically explores the international network development of regional forwarders. Collaboration between competing forwarders may create favourable condition and network sharing for each other. Lai and Cheng (2004) empirically study the freight forwarding industry in terms of demographic profiles, capabilities of providing different type of logistics services, service performance and the perceived prospects in Hong Kong. They explain many forwarders have high capability to provide freight forwarding and traditional logistics service, but they seem to lack the ability to provide other value-added service. Liang et al. (2006) pointed out four critical service items for an ocean freight forwarder. The four service items include operations convenience and response ability, integrated service, transportation ability, and price. Lu (2007) identifies seven capability dimensions for liner shipping including purchasing, operation, human resource management, customer service, information integration, pricing, and financial management. Results show four factors are significant differ between shipping companies and agency: marine equipment, information equipment, operation, and information integration. Stated the downturn of Hong Kong freight forwarding industry owing to the growing competition and challenge from the neighbouring ports of Yantian and Shekou in China, which operated in a much cheaper way. He suggested a tactical knowledge-based scheduling system implemented in a local freight forwarder for supporting the scheduling process of a shipping plan. Tongzon (2009) empirically studied on port choice issue from the freight forwarders' perspective in Southeast Asia. Efficiency is found to be the most significant factor followed by shipping frequency, adequate infrastructure and location. Lun et al. (2009) examine liner shipping from network perspective with an aim to develop a descriptive framework for operation and development of liner shipping networks. The framework supports liner shipping companies and their partners for cost and service improvement in renovating their networks. Shang (2009) empirically studied the organizational learning capabilities in third-party logistics providers in Taiwan. The results indicate the positive relationship between integration capability organizational learning capability and service performance. Lu and Yang (2010) empirically evaluated the crucial logistics service capabilities and firm performance of international distribution centre operators in Taiwan. Three key capabilities are innovation capability, customer response capability and flexible operation capability. Bock (2010) proposed a real-timeoriented control approach for freight forwarders to expand load consolidation, reduce empty vehicle trips, and handle dynamic disturbances. Feo et al. (2011) explored the preference analysis of Spanish freight forwarders modal choice between short sea shipping and door-to-door road transport in terms of value of time, value of reliability and value of frequency in freight transport.

\section{Attribute selection of customer requirement and technical measure}

Ministry of land, infrastructure and Transportation (2011) reveals important service quality items for third party logistics providers in Japan, including speedy delivery, price, schedule reliability, staff capability, problem handling, logistics solution and information providing ability. After logistics diagnosis by Japanese logistics consultant committee, several solutions are proposed such as improving technical support, 
solution to reduce cost and time, total logistics strategies, customer service support system and web-based information sharing. Su et al. (2011) explore the logistics innovation process in the health care supply chain and find the improved process may have positive impact on performance and financial result. Yang (2012) applied multiple regression analysis to explore the critical logistics service capabilities for ocean freight forwarders such as logistics service reliability, logistics value-added service capability, flexibility capability and logistics information capability. These factors had significant positive effects on financial performance. Propose a domainspecified quality of service (QoS) model to explore the web service technology of logistics industry with an aim to improve its business standards. Empirically examines customer relationship management (CRM) and its impacts on performance of freight forwarder services in Taiwan. The understanding of relationships among information technology, client response, knowledge management application, profit and managerial performance may offer a reference as to how freight forwarders can amend customer relationship to improve their performance. Vivaldini and Pires (2013) apply business cell approach to fourth party logistics freight management in Brazil. The results reveal better process integration to reduce cost and improved performance. Investigate the importance of information communication technology (ICT) to enhance the competitiveness in the shipping industry. ICT is also considered as the dynamic capabilities for shipping companies to survive in the complex environment. Supply chain consultant Crimson, says more demanding standards should be defined to European fresh food supply chains, but the cost may be high. The standards will define the details if the responsibility is belonging to origins of food, transport supplier or the retailers. The standards could also help all the party to pay attention to quality and source of food and monitor the supply chain from food supplier to end customer. Rogerson et al. (2014) propose the framework and purchase process of freight transport services, and the model suggest three dimensions such as purchase task, importance ranking and service type. After reviewing the above literature related to evaluation of the service quality, consulting with the president of leading forwarder companies, experienced executives, professors as well as shippers, we choose 12 customer requirements (CRs) in Tables 1 and 12 technical measures (TMs) to evaluate the service quality of freight forwarders in Table 2. Table 1 is the left part of $\mathrm{HoQ}$, and Table 2 is the upper part of HoQ. In Fig. 2, we lists several key performance indicators (KPI) and performance indicators (PI) of each technical measure to help decision makers understand the direction of quality improvement and its managerial meaning.

\section{Methodology}

\section{Definition of quality function deployment}

QFD is founded by Yoji Akao and first applied by shipping industry for Kobe shipyard for building of a new oil tanker ship. Following many applications in manufacture, service industry and public organization make QFD an important and popular methodology for quality improvement. QFD is a unique methodology to explore the important service quality as well as assessable technical measures for quality improvement. The house of quality (HoQ) is the main structure to complete QFD research. Literature 
Table 1 Customer requirements in the empirical work

\begin{tabular}{ll}
\hline Customer requirements & Description \\
\hline 1. Instant response & Speed to respond customer's request \\
2. Cheaper agency fee & Offer lower prices for customer. \\
3. Global service ability & Ability to provide global and local service \\
4. Tailor-made service & Provide service according to the request for individual customer \\
5. Door to door ability & Ability to deliver freight to customer's warehouse or designated location \\
6. Schedule reliability & No delay or cancel of delivery service \\
7. Consult service & Expert consult to provide supply chain and logistics solution \\
8. Excellent reputation & Company has good business records and trustworthy \\
9. Stable space supply & Ability to provide the space or handle large delivery \\
10. Fast document handling & Speed and easiness of documentation handling \\
11. Instant cargo tracking & Provide sophisticated dynamic or on-line tracking \\
12. Regular visit & Commercial visit to VIP customer \\
\hline
\end{tabular}

reviews show us several criticism and inadequacy of traditional QFD and how to improve this method. Therefore, many scholars take advantage of these characteristics and combine QFD with other techniques such as fuzzy, process management, DEA, AHP, MSE and SERVQUAL to solve service quality problems. (Duru et al., 2013) The combination of the techniques makes the research result more accurately and overcomes the original weakness and criticism of QFD method. Vanegas and Labib (2001) explain the QFD is an important tool to translate the Voice of customer (VOC) into the technical requirement. He applies the fuzzy numbers to optimize the relationship between customer requirement and technical requirement for the car door design and manufacture considering the cost, technical and market factors. Özgener (2003) stresses the evolution and advantage of QFD for product design and service management. However, the teamwork concept is key factor to make QFD successful because it will take more time and effort to get the best result. Arash and Chan (2006) improve QFD methodology by introducing the concept of customer requirement segmentation (CRS) for a four-star hotel. The contribution is to overcome the problems and difficulties such as ambiguities of VOC, handling of larger HoQ, conflict of each CR. Chen (2009)

Table 2 Technical measures in the empirical work

\begin{tabular}{ll}
\hline Technical Measures & Description \\
\hline 1. Overall information system & Implementing the system for information sharing \\
2. Paperless and simple procedure & Easiness and convenience to handle customer paperwork \\
3. Quality manual and certificate & Clear procedure to define corporate goal and job details \\
4. Customer clearance & Efficient custom clearance procedure \\
5. Service point and network & Office or service centre overseas and service route \\
6. Customer relationship management & Work closely with customer to build relationship and commitment \\
7. IT implementation & Applying new technology to improve efficiency of cargo operation \\
8. Human resource management & Train potential employees for their valuable contribution in the future \\
9. Strong intermodal ability & Ability to provide efficient mode combination to complete delivery \\
10. Marketing strategy & Clear marketing goal to both VIP or general customer \\
11. Free consulting service & Free market and supply chain information consulting \\
12. Green shipping policy & Environmental friendly transport and low coz emission commitment \\
\hline
\end{tabular}




\section{Overall information systems \\ a. Web interface \\ i. Sufficient information in website \\ ii. Real time information available \\ iii. Online responsiveness \\ iv. Information sharing \\ v. Existence of intranet \\ vi. Dynamic cargo tracking systems \\ vii. EDI systems}

2. Paperless and simple procedure

a. Paperless work and easy documentation

i. Digital to paperless ration (eg. $40 \%$ )

ii. Average time for customer service (hrs)

iii. Labour to automation ratio (eg. $10 \%$

3. Quality manual and certificate

a. Certificate

i. Number of certificate issued by

ii. international organization

ii. Annual budgeting for defining

iii. Clear standard operating procedure

iv. Number of annual meeting of standard and procedure

v. Compliance with corporate social responsibility policy(CSR)

\section{Custom clearance}

a. CIQ process time

i. Average time for custom clearance (hrs) ii. Automated custom system

iii. Smooth route planning for $\mathrm{ClQ}$ process

iv. All day operation

5. Service point and network

a. Office and service point

i. Number of offices

ii. Number of local staffs

iii. Number of local agents

v. Global service network

- Partnership with other logistics service providers

vi. Number of self-owned truck

vii. Number of self-owned aircraft

of self-owned ships

6. Customer relationship management

a. Customer service

i. Number of customer service staff

ii. Number of commercial visit

iii. One stop shop for customer service

iv. Annual meeting for customer service

v. Budget for strengthening customer relationship (USD)

vi. Strengthen relationship with traders

vii. Strengthen relationship with

manufactures and other shippers

viii. Strengthen relationship with other

ix. Tailor-made service ability

\section{IT implementation}

a. Advance IT facility

i. Application of advance IT facility

ii. Number of automated warehouse or

iii. Dynamic cargo tracking facilities

iv. Dymanic cargo tracking facilities

v. Number of advance IT terminals

vi. Number of advance exclusive aprons

8. Human resource Management a. Human cost, training and knowledge

i. Annual labour and staff cost(USD)

ii. Budget for staff training (USD)

iii. Number of external lectures

iv. Number of attending academic conferences

v. Number of attending industrial meetings

vi. External HR consultant

vii. Number of projects with maritime university

b. Performance evaluation

i. Bonus systems

ii. Number of external auditor

. Number of visiting other service providers

c. Learning and knowledge management

i. Number of visiting other famous

forwarder companies

ii. Number of external auditor and

consultants

Regular meeting with government and

9. Strong intermodal ability

a. Intermodal ability

i. Logistics solution providing

iii. Number of intermodal solution meeting

and regular meeting

iv. Budget for intermodal solution (USD)

v. Collabo

vi. End to end logistics solution ability

10. Marketing strategy

a. Marketing activities

. Annual budget for marketing (USD)

ii. Annual budget for advertisement (USD)

- Annual budget for new product

developing(USD)

iv. Number of promotional activities

v. Number of meeting for developing new selling channels

vi. Number of commercial visit

vii. Negotiable price with mega liner carrie

ix. Partnership with foreign liner and logistics service provider

11. Free consulting and support service

a. Internal and external consulting

i. Number of internal consultants

iii. Number of research experts

iv. Annual policy meeting

v. Information providing service

vi. Business solution properal

b. Local contact and information

i. Local market experts

ii. Local support and knowledge sharing

iii. Customer information centre

research institution

. Research projects with local experts to support client's difficulties

12. Green shipping policy

. Emission reduction

i. Annual budget for emission policy (USD)

year (m3)

iii. Greenhouse gas (GHG) reduction (m3)

iv. Cargo handling equipment with

- emission reduction technology

v. Green policy compliance with local and

international regulation

i. Number of meeting for green policy

vi. Measure for encouraging emission

reduction

viii. Green measurement with stakeholders or container terminal operators

Fig. 2 List of technical measures of international freight forwarder, KPIs and PIs

innovatively integrates the concept of QFD and process management techniques to meet customer requirement and company goals in terms of product design, process management in semiconductor industry. Process management is an important concept of Six Sigma implementation and may be significantly improved by applying the QFD method. Ip (2009) creates a model for business succession such as assessment of current situation of business, successor and competencies analysis and planning of necessary tasks for future development by utilizing the QFD method. Combine QFD and 
mean square error (MSE) criterion to evaluate the bank service. The important service dimensions are service quality, staff attitude, information providing, technology and management feature. Pakdil et al. (2012) apply QFD to analyze the after sales services both qualitatively and quantitatively for a manufacture firms. SERVQUAL and factor analysis are also used to include the house of quality. Explore the Spanish small medium sized enterprises to discuss their certified quality management systems and logistics performances. Their current standard is ISO 9001. The authors proposed the more specific logistics management standards may be needed to improve the process. Kilibarda et al. (2016) use SERVQUAL model to evaluate the logistics service quality of freight forwarder. Factor analysis and ANOVA are conducted to explore best service quality items. Gil-Saura et al. (2018) explore the service quality of freight forwarder in B2B relationship through ANOVA and SEM process. Archetti and Peirano (2019) explore air freight forwarder's service problem and find the simulation model to optimize its intermodal service problem.

The QFD framework is proposed to translate customer requirements (CRs) into technical requirements (TMs) by constructing HoQ matrix as shown in Fig. 3. We could obtain the priority degree of TMs through computing the sum product of relative weight of each CR. After normalizing the value of result, the obtained relative weight could show the relationship degree of TM for enhancing customer satisfaction. The conventional HoQ matrix consists of seven major parts including the customer requirements (CRs), the priority degree for requirements, technical measures (TMs), the correlation matrix (between TMs), relationship matrix (between TMs and CRs), sum products of priority degrees and relationship degrees, wj, and the priority degree of

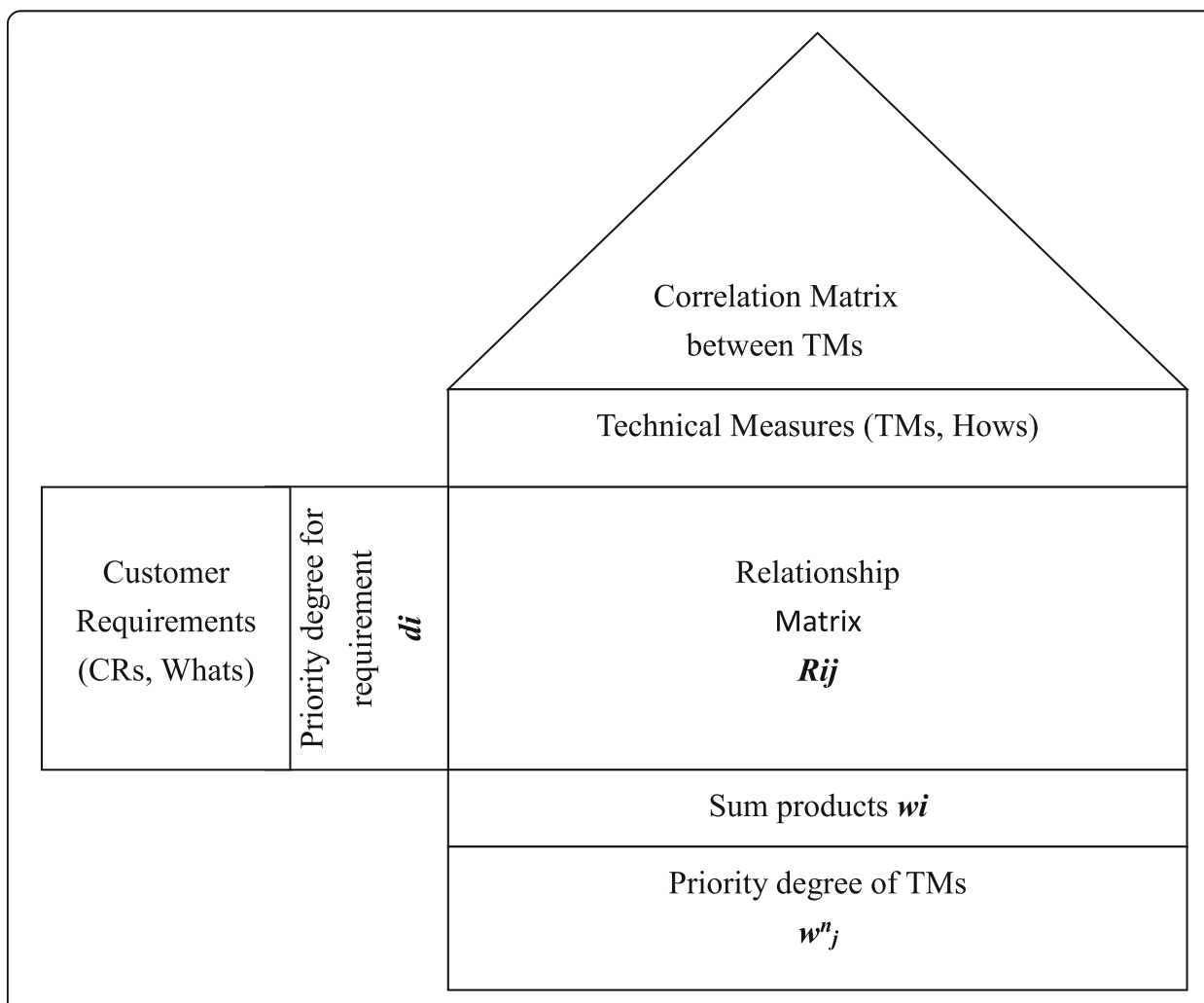

Fig. 3 Structure of house of quality 
TMs, wnj. The correlation matrix is mainly practical for developing strategies to improve technical measures. In some cases, a technical measure has a positive or negative correlation and an improvement may give to another or deteriorate it. For evaluation of the balance of improvements, correlation matrix signifies such interactions.

The numerical procedure for assignment of priority degree of TMs is as follows:

Given $m$ customer requirements signified by $C R i,(i=1,2, \ldots, m)$ and $n$ technical measures signified by $T M i(i=1,2, \ldots, n)$. Let $d i(i=1,2, \ldots, \mathrm{m})$ be the priority degree for the $i$ th $C R i$ among the whole set of CRs, whereas $w j(j=1,2, \ldots, n)$ signifying the relative weight of importance of the jth TM, is determined from the relationship between TMs and CRs. Let $R$ be the relationship matrix between TMs and CRs, the component $R i j$ signifies the level of impact of the jth TM on satisfaction of the $i$ th CR. The value of $R i j$ is assigned by an indicator value of 9 (Strong relationship, $\mathbf{m}), 5$ (Moderate relationship, $\mathbf{\Delta}$ ), 1 (Low relationship, $\bullet$ ) or 0 (No relationship, “ø”).The sum product of the priority degree, $d i$ of the $i$ th $C R i$ and $R i j$ is calculated as follows;

$$
w_{j}=\sum_{i=1}^{m} d_{i} R_{i j}, \mathrm{j}=1,2, \ldots, \mathrm{n}
$$

The priority degree for the CRs, di, is defined by an original FAHP process through the pair wise comparison survey.

In this study, the relative weight of customer requirement is defined by using FAHP and applied to calculate the technical measures. This combination with FAHP could improve the classic QFD method by determining the relative weight quantitatively and assessing the relationship between requirements precisely. Second, the technical measure would be obtained for the priorities of enhancing customer satisfaction. By analysis and discussion of the result, the meaningful business solution could be proposed for enhancing customer satisfaction.

\section{Fuzzy analytic hierarchy process}

After introducing fuzzy method by Zadeh (1965), Van Laarhoven and Pedrycz (1983) extended analytic hierarchy process (AHP) by using fuzzy approach to deal with vagueness of human thought for decision making problem. They used a triangular fuzzy numbers (TFNs) to develop fuzzy-AHP (FAHP) method. In the FAPH method, the judgement matrix is formed in a pair-wise comparison matrix which is calculated fuzzy arithmetic and fuzzy aggregation operators and the procedure calculated a sequence of weight vectors that can be used to choose main attribute. In existing literature, many studies investigate the decision problems under uncertainty condition by using FAHP methods (Bozbura \& Beskese, 2007; Bulut et al., 2012; Duru et al., 2013; Gumus, 2009). In this paper, Chang's approach is used for the FAHP calculation and its algorithm is as follows (Chang, 1996); Let $X=\{\times 1, \times 2, \ldots, x n\}$ be an object set and $U=\{u 1, u 2, \ldots, u m\}$ be a goal set. According to the method of extent analysis, each object is taken and extent analysis for each goal is performed, respectively (Chang, 1996). Therefore, $\mathrm{m}$ extent analysis values for each object can be obtained, with the following signs:

$$
M_{g_{i}}^{1}, M_{g_{i}}^{2}, \ldots, M_{g_{i}}^{m}, \quad i=1,2, \ldots, n,
$$

where all the $M_{g}^{j}(\mathrm{j}=1,2, \ldots, \mathrm{m})$ are TFNs. 
The steps of Chang's extent analysis can be given as in the following:

Step 1: The value of fuzzy synthetic extent with respect to the ith object is defined as

$$
S_{i} \sum_{j=1}^{m} M_{g_{i}}^{j} \otimes\left[\sum_{i=1}^{n} \sum_{j=1}^{m} M_{g_{i}}^{j}\right]^{-1}
$$

To obtain $\sum_{j=1}^{m} M_{g_{i}}^{j}$, the fuzzy addition operation of $m$ extent analysis values for a particular matrix is performed such as:

$$
\sum_{j=1}^{m} M_{g_{i}}^{j}=\left(\sum_{j=1}^{m} l_{j}, \sum_{j=1}^{m} m_{j}, \sum_{j=1}^{m} u_{j}\right)
$$

And to obtain $\left[\sum_{i=1}^{n} \sum_{j=1}^{m} M_{g_{i}}^{j}\right]^{-1}$, the fuzzy addition operation of $M_{g_{i}}^{j}(\mathrm{j}=1,2, \ldots, \mathrm{m})$ values is performed such as:

$$
\sum_{i=1}^{n} \sum_{j=1}^{m} M_{g_{i}}^{j}=\left(\sum_{j=1}^{m} l_{j}, \sum_{j=1}^{m} m_{j}, \sum_{j=1}^{m} u_{j}\right)
$$

and then the inverse of the vector in Eq. (5) is computed, such as:

$$
\left[\sum_{i=1}^{n} \sum_{j=1}^{m} M_{g_{i}}^{j}\right]^{-1}=\left(\frac{1}{\sum_{i=1}^{n} u_{i}}, \frac{1}{\sum_{i=1}^{n} m_{i}}, \frac{1}{\sum_{i=1}^{n} l_{i}}\right)
$$

Step 2: The degree of possibility of $M 2=(12, \mathrm{~m} 2, \mathrm{u} 2) \geq \mathrm{M} 1=(11, \mathrm{~m} 1, \mathrm{u} 1)$ is defined as

$$
V\left(M_{2} \geq M_{1}\right)=\sup _{y \geq x}\left\lfloor\min \left(\mu_{M_{1}}(x), \mu_{M_{2}}(y)\right)\right\rfloor
$$

and can be expressed as follows:

$$
V\left(M_{2} \geq M_{1}\right)=h g t\left(M_{1} \cap M_{2}\right)=\mu_{M_{2}}(d)=\left\{\begin{array}{c}
1, \text { if } m_{2} \geq m_{1}, \\
0, \text { if } l_{1} \geq u_{2}, \\
\frac{l_{1}-u_{2}}{\left(m_{2}-u_{2}\right)-\left(m_{1}-l_{1}\right)}, \text { otherwise. }
\end{array}\right.
$$

Figure 4 illustrates Eq. 8 where $\mathrm{d}$ is the ordinate of the highest intersection point $\mathrm{D}$ between $\mu_{M_{1}}$ and $\mu_{M_{2}}$. To compare M1 and M2, we need both the values of V (M1 $\geq$ $\mathrm{M} 2)$ and $\mathrm{V}(\mathrm{M} 2 \geq \mathrm{M} 1)$.

Step 3: The degree possibility for a convex fuzzy number to be greater than $\mathrm{k}$ convex fuzzy Mi $(\mathrm{i}=1,2, \ldots, \mathrm{k})$ numbers can be defined by.

$$
\begin{aligned}
V\left(M \geq M_{1}, M_{2}, \ldots, M_{k}\right) & =V\left[\left(M \geq M_{1}\right) \text { and }\left(M \geq M_{2}\right) \text { and } \ldots \text { and }\left(M \geq M_{k}\right)\right] \\
& =\min V\left(M \geq M_{i}\right), i=1,2,3, \ldots, k
\end{aligned}
$$

Assume that $d^{\prime}(A i)=\min V(S i \geq S k)$ for $k=1,2, \ldots, n ; k \neq i$. Then the weight vector is given by. 


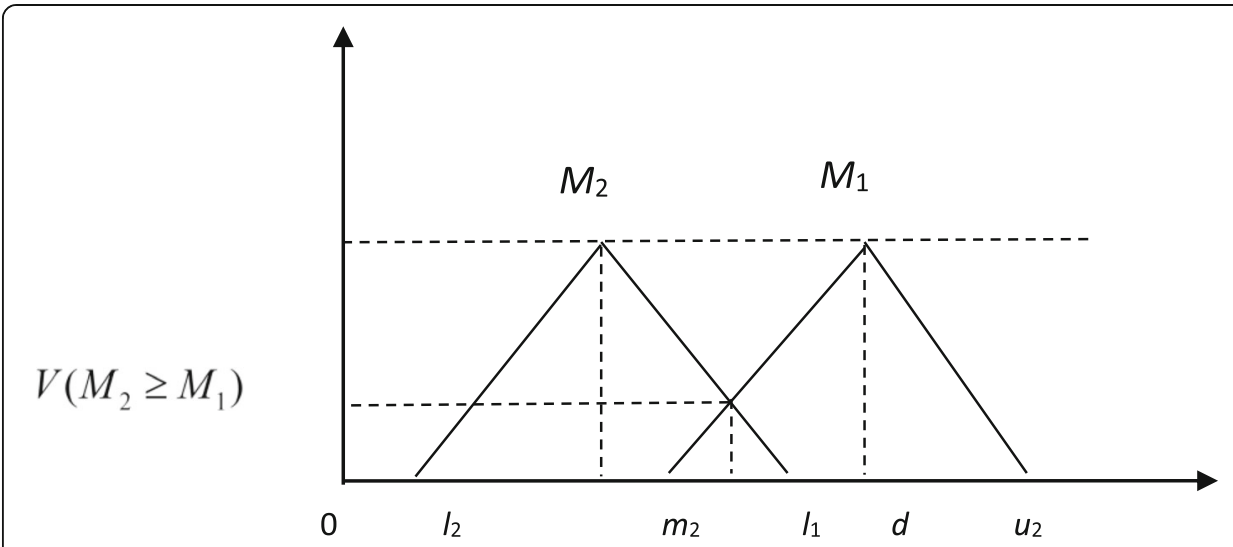

Fig. 4 The intersection between $M 1$ and $M 2$

$$
W^{\prime}=\left(d^{\prime}(A 1), d^{\prime}(A 2), \ldots, d^{\prime}(A n)\right) T
$$

Where $\mathrm{Ai}(\mathrm{i}=1,2, \ldots, \mathrm{n})$ are $\mathrm{n}$ elements.

Step 4: Via normalization, the normalized weight vectors are.

$$
W=(d(A 1), d(A 2), \ldots, d(A n)) T,
$$

where $\mathrm{W}$ is a non-fuzzy number.

Table 3 displays the linguistic comparison terms and their equivalent fuzzy numbers in this paper.

\section{The consistency calculation for the FAHP method}

Duru et al. (2013) proposed the centric consistency index (CCI) for the consistency calculation of FAHP method and it is based on geometric consistency index (GCI).

The calculation of $\mathrm{CCI}$ is as follows;

Let $\mathrm{A}=(\mathrm{aLij}, \mathrm{aMij}, \mathrm{aUij}) \mathrm{n} \times \mathrm{n}$ be a fuzzy judgment matrix, and let $\mathrm{w}=[(\mathrm{wL} 1, \mathrm{wM} 1$, $\mathrm{wU} 1),(\mathrm{wL} 2, \mathrm{wM} 2, \mathrm{wU} 2), \ldots,(\mathrm{wLn}, \mathrm{wMn}, \mathrm{wUn})] \mathrm{T}$ be the priority vector derived from $A$ using the RGMM. The centric consistency index (CCI) is computed by

$$
\begin{aligned}
C C I(A)= & \frac{2}{(n-1)(n-2)} \sum_{i<j}\left(\log \left(\frac{a_{L i j}+a_{M i j}+a_{L i j}}{3}\right)-\log \left(\frac{w_{L i}+w_{M i}+w_{L i}}{3}\right)\right. \\
& \left.+\log \left(\frac{w_{L j}+w_{M j}+w_{U j}}{3}\right)\right)^{2}
\end{aligned}
$$

When $C C I(A)=0$, we consider $A$ fully consistent. Also provide the thresholds $(\overline{G C I})$ as $\overline{G C I}=0.31$ for $n=3$; $\overline{G C I}=0.35$ for $n=4$ and $\overline{G C I}=0.37$ for $n>4$. When $C C I(A)<$

Table 3 The linguistic comparison terms and their equivalent fuzzy numbers

\begin{tabular}{llll}
\hline Fuzzy number & Linguistic scales & Membership function & Inverse \\
\hline$\tilde{A}_{1}$ & Equally important & $(1,1,1)$ & $(1,1,1)$ \\
$\tilde{A}_{2}$ & Moderately important & $(1,3,5)$ & $(1 / 5,1 / 3,1)$ \\
$\tilde{A}_{3}$ & More important & $(3,5,7)$ & $(1 / 7,1 / 5,1 / 3)$ \\
$\tilde{A}_{4}$ & Strongly important & $(5,7,9)$ & $(1 / 9,1 / 7,1 / 5)$ \\
$\tilde{A}_{5}$ & Extremely important & $(7,9,9)$ & $(1 / 9,1 / 9,1 / 7)$ \\
\hline
\end{tabular}


$\overline{G C I}$, it is considered that the matrix $A$ is sufficiently consistent. Since the CCI is a fuzzy extended version of the GCI, thresholds remain identical.

The prioritization of decision maker

The weight of each decision makers is different than each other because their experience and thought about the problem differ from each other. In this paper, therefore, the reverse value of CCI is considered as their prioritization and it is used the calculation of the aggregated fuzzy judgment matrix for the criteria of customer satisfactions (Duru et al., 2013).

Let $A=\left(a_{i j}\right)_{n \times n}$, where $a_{i j}>0$ and $a_{i j} \times a_{j i}=1$, be a judgment matrix. The prioritization method refers to the process of deriving a priority vector of criteria $\mathrm{w}=\left(w_{1}, w_{2}, \ldots, w_{n}\right)^{\mathrm{T}}$, where $w_{i} \geq 0$ and $\sum_{i=1}^{n} w_{i}=1$, from the judgment matrix $A$.

Let $D=\left\{d_{1}, d_{2}, \ldots, d_{m}\right\}$ be the set of decision makers, and $\lambda_{k}=\left\{\lambda_{1}, \lambda_{2}, \ldots, \lambda_{m}\right\}$ be the priority vector of decision makers. The priority vector of decision makers $\left(\lambda_{k}\right)$ is the normalized $\mathrm{I}_{\mathrm{k}}$ for the group of experts which is calculated as follows:

$$
I_{k}=\frac{1}{C C I_{k}}
$$

where Ik is the inverse of the CCI normalization,

$$
\lambda_{k}=\frac{I_{k}}{\sum_{k=1}^{m} I_{k}}
$$

where $\lambda \mathrm{k}>0, \mathrm{k}=1,2, \ldots, \mathrm{m}$, and $\sum_{k=1}^{m} \lambda_{k}=1$.

Let $\mathrm{A}(\mathrm{k})=\left(a_{i j}^{(k)}\right)_{n \times n}$ be the judgment matrix provided by the decision maker $\mathrm{dk}$.

$w_{i}^{(k)}$ is the priority vector of criteria for each decision maker calculated by

$$
w_{i}^{(k)}=\frac{\left(\prod_{j=1}^{n} a_{i j}\right)^{1 / n}}{\sum_{i=1}^{n}\left(\prod_{j=1}^{n} a_{i j}\right)^{1 / n}}
$$

The aggregation of individual priorities is defined by

$$
w_{i}^{(w)}=\frac{\prod_{k=1}^{m}\left(w_{i}^{(k)}\right)^{\lambda_{k}}}{\sum_{i=1}^{n} \prod_{k=1}^{m}\left(w_{i}^{(k)}\right)^{\lambda_{k}}}
$$

where $w_{i}^{(w)}$ is the aggregated weight vector. After the aggregation process, the extent synthesis methodology of Chang (1996) is applied for subsequent choice selection.

\section{The empirical study on freight forwarder in East Asia}

Several leading freight forwarders are selected to explore for service quality evaluation and technical measures are used to evaluate customer satisfaction in East Asian region. Selected 15 consultation experts include professors, president, senior executives and practitioners and the name of company is kept confidential. The data is collected by email, telephone and personal visits. The consultation is performed according to the following steps. In the first step, an initial survey is arranged to define the appropriate 
customer requirements and technical measures for evaluation. Then, the primary survey is performed to complete cross relationship matrix in the second step. The FAHP is applied to define relative weight for the priorities of customer requirement. The expert group is asked to complete a pair wise comparison survey. Table 4 shows the aggregate fuzzy judgement matrix for the customer requirement. $\mathrm{CCI}$ is 0.01 which is less than the critical value of 0.37 . The top three customer requirements are cheaper agency fee (0.19), door to door ability (0.16) and instant response (0.15). First of all, "cheaper agency fee" is the top customer requirement. Forwarders should provide competitive prices by reducing operational cost or financial planning as Porter's (1998) cost leadership approach. Second, "door to door ability" shows us the current customer's high expectation of forwarder's logistics solution in terms of time, cost and reliability. This means forwarders should work closely with partners such as truck, rail or other inland transportation firms to ensure logistics capability. Third, "instant response"shows the importance of information providing. Forwarders should have sophisticated tracking system and quick response to customer's question.

\section{Managerial implication and conclusion}

The top four relative weight of technical measures are customer relationship management (0.16), overall information system (0.14), service point and network (0.14) as shown in Table 5. The finding and proposed practical application could be useful information and supportive function for decision making process. First, the most important technical measure is "customer relationship management." Forwarder business is highly competitive business and may be easily replaced by other logistics service provider. Interaction and commitment from value customer is indispensable to success in this business.

Second, "overall information system" may be an important tool for reducing cost, instant response and efficiency improvement. Bjorn et al. (2012) also empirically explore how the information systems improve maritime logistics from tracking stock level, vessel space allocation, transport and inventory cost reduction. The utilization can support the decision making from operational, tactical, and strategic levels within maritime logistics. Therefore, implementing advance information system could effectively support the customer and enhance the efficiency.

Third, regarding "service point and network", forwarders may expand its service coverage and network through more partnerships with major carriers or local logistics service providers. Many global freight forwarders play the role as a local company, so the local knowledge and expertise becomes a barrier for market entry. When service and network of forwarder business expands globally, the important of reliable local partner is indispensible factor for business success. Therefore, the forwarders should

Table 4 The aggregated fuzzy judgment matrix for customer requirements

\begin{tabular}{|c|c|c|c|c|c|c|c|c|c|c|c|c|c|}
\hline 口 & $\mathrm{Cl}$ & $\mathrm{C}_{2}$ & $\mathrm{C}_{3}$ & C4 & $\mathrm{cs}$ & $\begin{array}{ll}66 \\
\end{array}$ & $\mathrm{C} 7$ & $c 8$ & $\mathrm{Cg}$ & $\mathrm{C}_{10}$ & $\mathrm{C} 11$ & $\mathrm{C} 12$ & Welght \\
\hline 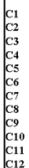 & 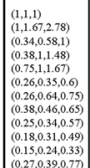 & 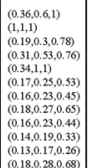 & 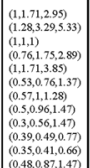 & 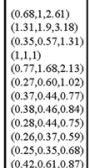 & 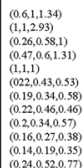 & 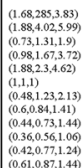 & 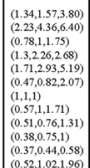 & 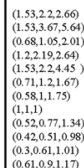 & 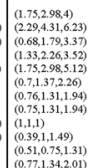 & 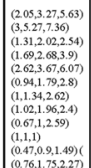 & 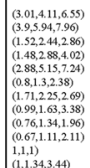 & 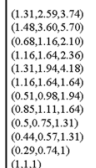 & $\begin{array}{l}0.015 \\
0.19 \\
0.09 \\
0.12 \\
0.16 \\
0.07 \\
0.07 \\
0.07 \\
0.09 \\
0.02 \\
0.01 \\
0.01\end{array}$ \\
\hline
\end{tabular}


Table 5 House of quality matrix for customer requirements and technical measures

\begin{tabular}{|c|c|c|c|c|c|c|c|c|c|c|c|c|c|c|c|}
\hline \multicolumn{6}{|c|}{ HoQ of Customer Satisfaction } & & & & \multicolumn{7}{|c|}{$\operatorname{Maximize}(\mathbf{\Lambda})$, Minimize $(\mathbf{V})$ and Target $(\mathrm{X})$} \\
\hline & & & Direction of improvement & & & & & & & & & & & & \\
\hline 竞 & 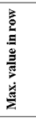 & 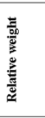 & & 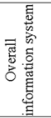 & 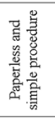 & 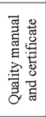 & 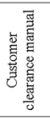 & 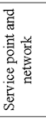 & 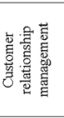 & 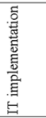 & 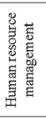 & 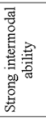 & 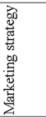 & 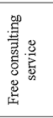 & 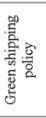 \\
\hline 1 & 9 & 0.15 & Instant response &.$"$ & • & $\Delta$ & $\Delta$ & $\Delta$ & - & $\because$ & - & $\Delta$ & $\Lambda$ & - & - \\
\hline 2 & 5 & 0.19 & Cheaper agency fee & - & - & - & & - & $\Delta$ & & & & $\Delta$ & & \\
\hline 3 & 9 & 0.09 & Global service ability & $\Delta$ & - & $\Delta$ & $\Delta$ & - & - & - & $\Delta$ & $\Delta$ & $\Delta$ & $\Delta$ & \\
\hline 4 & 5 & 0.12 & Tailor-made service & $\Delta$ & • & & • & $\Delta$ & $\Delta$ & • & - & $\Delta$ & & - & \\
\hline 5 & 9 & 0.16 & Door to door ability & - & & $\Delta$ & - & - & $\Delta$ & $\Delta$ & - & - & - & & - \\
\hline 6 & 9 & 0.07 & Schedule reliability & - & & - & - & $\Delta$ & • & - & $\Delta$ & $\Delta$ & - & - & \\
\hline 7 & 5 & 0.07 & Consult service & - & & - & & - & $\Delta$ & - & - & $\Delta$ & - & - & \\
\hline 8 & 9 & 0.06 & Excellent reputation & $\Delta$ & • & $\Delta$ & - & - & - & - & $\Delta$ & • & - & - & $\Delta$ \\
\hline 9 & 5 & 0.05 & Stable space supply & - & & - & & $\Delta$ & - & • & & - & $\Delta$ & - & \\
\hline 10 & 9 & 0.02 & Fast document handling & $\Delta$ & - & - & $\Delta$ & & $\Delta$ & $\Delta$ & - & & - & - & \\
\hline 11 & 9 & 0.01 & Instant cargo tracking & - & & - & - & - & - & - & & $\Delta$ & & & \\
\hline \multirow[t]{5}{*}{12} & 9 & 0.01 & Regular visit & & - & - & & & - & & $\Delta$ & & $\Delta$ & - & \\
\hline & & & Max. value in column & 9 & 9 & 5 & 9 & 9 & 9 & 9 & 5 & 9 & 5 & 9 & 5 \\
\hline & & & Sum product & 5.27 & 0.8 & 2.72 & 3 & 5.09 & 5.72 & 3.52 & 1.67 & 4.1 & 2.83 & 1.56 & 0.61 \\
\hline & & & Relative weight & 0.14 & 0.02 & 0.07 & 0.08 & 0.14 & 0.16 & 0.1 & 0.05 & 0.11 & 0.08 & 0.04 & 0.02 \\
\hline & & & Rank & 2 & 11 & 8 & 6 & 3 & 1 & 5 & 9 & 4 & 7 & 10 & 12 \\
\hline
\end{tabular}

not only cooperate with logistics service providers as well as deeply connect with local stakeholders for serving their customers.

The result of the research reveals important technical measures for quality improvement of freight forwarder in East Asian countries, and we collect practitioner's comments and feedback regarding to our research findings as managerial implication. They explain the relationship with customer is particularly significant because the importance of private relationship may be key factor for long term contract and partnership especially in East Asia. Therefore, strengthen the relationship with shipper may be the primarily mission. On the other hand, investment of IT facilities is indispensable to maintain the satisfactory service level. The integrated information system with carriers may help forwarder to improve efficiency. Finally, the comprehensive service network is also essential to provide shipper the global service. Freight forwarders may strengthen their network by cooperating with more reliable local partners such as truck or railway firms.

\section{Acknowledgements}

Not applicable.

\section{Authors' contributions}

All authors read and approved the final manuscript.

\section{Author's information}

Sheng Teng Huang is an Assistant Professor in the Department of Transportation. Science at the National Taiwan Ocean University (NTOU), Keelung, Taiwan. He received his PhD from Kobe University, Japan. His main research interests are Japanese shipping industry, logistics and delivery management. He has several journal and conference papers. He has the memberships of Japan Society of Logistics and Shipping. Economics (JSLSE) and International Association of Maritime Economics (IAME). He also reviews papers for International Journal of Production Research (IJPR) and International Journal of Shipping and Transport Logistics (IJSTL).

Emrah Bulut is an Assistant Professor in the Department of Business Administration at the Yıldız Technical University and received his PhD from Kobe University, Japan. His research interests are in shipping business management and behavioral decisionmaking. He contributes several studies related to the decision support systems, group decisionmaking under uncertainty, behavioral finance, time series forecasting and fuzzy extended time series analysis. He has published several journal and conference papers. He has memberships of the American Finance Association (AFA), International. Association of Maritime Economics (IAME) and Korean Association of Shipping and Logistics (KASL). He also reviews papers for, Transport Policy (JTRP), Asian Journal of Shipping \& Logistics (AJSL), European Journal of Operational Research (EJOR), and Fuzzy Sets and Systems (FTS).

Okan Duru is an Assistant Professor of Nanyang Technological University, Singapore. He holds a PhD in Maritime Science (Maritime Logistics) from Kobe University, Japan. His research interests are in shipping asset management, behavioral economics of shipping business, forecasting, judgment and decision making. He has published many 
journal papers and conference papers as well as editing journal issues. He reviewed several papers for Maritime Policy and Management, International Journal of Forecasting, Transportation Research Part E: Logistics and Transportation Review, Technological Forecasting and Social Change, European Journal of Operational Research, Journal of the Operational Research Society-JORS, Applied Soft Computing, Fuzzy Sets and Systems, International Journal of Fuzzy Systems, among others.

\section{Funding}

There were no additional sources of funding for this research.

\section{Availability of data and materials}

Not applicable

\section{Competing interests}

The authors declare that they have no competing interests.

\section{Author details}

1Department of Transportation Science, National Taiwan Ocean University, Keelung 20224, Taiwan, Republic of China. ${ }^{2}$ Department of Business Administration, Yildiz Technical University, Besiktas, 34349 Istanbul, Turkey. ${ }^{3}$ School of Civil and Environmental Engineering, Nanyang Technological University, 50 Nanyang Avenue, N1-01c-95, 639798 Singapore, Singapore.

\section{Received: 27 September 2018 Accepted: 31 October 2019}

\section{Published online: 17 December 2019}

\section{References}

Arash S, Chan JFL (2006) Customer requirements segmentation (CRS): A prerequisite technique for quality function deployment (QFD). Total Quality Management \&Business Excellence 1(5):567-581

Archetti C, Peirano L (2019) Air intermodal freight transportation: the freight forwarder service problem. Omega

Bjorn EA, Haakon L, Jan TP (2012) Information technology in maritime logistics management: a case-based approach from COA to SLA. In: Song DW, Panayides PM (eds) Maritime Logistics Contemporary Issues. Emerald Group Publishing UK

Bock S (2010) Real-time control of freight forwarder transportation networks by integrating multimodal transport chains. European Journal of Operational Research 200(3):733-746

Bozbura FT, Beskese A (2007) Prioritization of organizational capital measuremen indicators using fuzzy AHP. International Journal of Approximate Reasoning 44:124-147

Brooks MR (1985) An alternative theoretical approach to the evaluation of liner shipping Part II. Choice criteria. Maritime Policy \& Management: The flagship journal of international shipping and port research 12(2):145-155

Bulut, E., Duru, O., Keçeci, T. \& Yoshida, S. (2012),"Use of consistency index, expert prioritization and direct numerical inputs for generic fuzzy-AHP modeling: A process model for shipping asset management, Expert Systems with Applications, Vol. 39, pp.1911-1923.

Chang DY (1996) Applications of the extent analysis method on fuzzy AHP. European Journal of Operational Research 95:649-655

Chen CC (2009) Integration of quality function deployment and process management in the semiconductor industry. International Journal of Production Research 47(6):1469-1484

Duru O, Huang ST, Bulut E, Yoshida S (2013) Multi-Layer Quality Function Deployment (QFD) approach for improving the compromised quality satisfaction under the agency problem: A 3D QFD design for the asset selection problem in the shipping industry. Quality \& Quantity 47(4):2259-2280

Feo VM, Menéndez LG, Hidalgo RG (2011) Valuing Freight Transport Time using Transport Demand Modelling: A BibliographicalReview. Transport Reviews: A Transnational Transdisciplinary Journal 31(5):625-651. https://doi.org/10.1080/ 01441647.2011 .564330

Gil-Saura I, Berenguer-Contri G, Ruiz-Molina E (2018) Satisfaction and loyalty in B2B relationships in the freight forwarding industry: adding perceived value and service quality into equation. Transport 33(5):1184-1195

Gumus, A. T. (2009),"Evaluation of hazardous waste transportation firms by using a two step fuzzy-AHP and TOPSIS methodology, Expert Systems with Applications, Vol. 36, pp.4067-4074.

Ip B (2009) Planning and controlling business succession planning using quality function deployment. Total Quality Management \& Business Excellence 20(4):363-379

Kilibarda M, Nikolicic S, Andrejic M (2016) Measurement of logistics service quality in freight forwarding companies: a case study of the Serbian market. The International Journal of Logistics Management 27(3):770-794

Lai KH, Cheng TCE (2004) A study of the freight forwarding industry in Hong Kong. International Journal of Logistics Research and Applications: A LeadingJournal of Supply Chain Management 7(2):71-84

Liang GS, Chou TY, Kan SF (2006) Applying fuzzy quality function deployment to identify service management requirements for an ocean freight forwarder. Total Quality Management \& Business Excellence 17(5):539-554. https://doi.org/10.1080/ 14783360600587994

Lloyd's List, 2014, Ports and Logistics. (http://www.lloydslist.com/ll/world/).

Lu CS (2007) Evaluating key resources and capabilities for liner shipping services. Transport Reviews: A Transnational Transdisciplinary Journal 27(3):285-310

Lu YZ, Dinwoodie J (2002) Comparative perspectives of international freight forwarder services in China. Transportation Journal 42(2):17-27

Lun YHV, Lai KH, Cheng TCE (2009) A descriptive framework for the development and operation of liner shipping networks. Transport Reviews: A Transnational Transdisciplinary Journal 29(4):439-457 
Ministry of Land, Infrastructure and Transportation (2011) Key service quality attributes of third party logistics service providers. Yearbook of Ministry of Land, Infrastructure and Transportation, Tokyo, pp 170-180

Özgener Z (2003) Quality function deployment: A teamwork approach. Total Quality Management \& Business Excellence 14(9):969-979

Pakdil F, Işı FB, Genç H (2012) A quality function deployment application using qualitative and quantitative analysis in after sales services. Total Quality Management \& Business Excellence 23(11):1397-1411

Porter ME (1998) Competitive strategy: Techniques for analyzing Industries and competitors: with a new introduction. the Free Press, New York

Rogerson S, Andersson D, Johansson MI (2014) Influence of context on the purchasing process for freight transport services. International Journal of Logistics Research and Applications: A Leading Journal of Supply Chain Management 17(3):232248. https://doi.org/10.1080/13675567.2013.843655

Shang KC (2009) Integration and organisational learning capabilities in third-party logistics providers. The Service Industries Journal 29(3):331-343

Su S, Ivan L, Britta GL, Su LY (2011) Logistics innovation processrevisited:insights from a hospital case study. International Journal of Physical Distribution \& Logistics Management 41(6):577-600

Tongzon JL (2009) Port choice and freight forwarders. Transportation Research Part E-Logistics and Transportation Review 45(1):186-195

UNCTAD Secretariat (2013) Review of Maritime Transport of United Nations, Geneva

Van Laarhoven PJM, Pedrycz W (1983) A fuzzy extension of Saaty's priority theory. Fuzzy Sets and Systems 11:199-227

Vanegas LV, Labib AW (2001) A Fuzzy Quality Function Deployment (FQFD) model for deriving optimum targets. International Journal of Production Research 39(1):99-120

Vivaldini M, Pires SRI (2013) Applying a business cell approach to fourth-party logistics freight management in the food service industry. International Journal ofLogistics Research and Applications: A Leading Journal of Supply Chain Management 16(4):296-310

World Trade Organization (2013) International trade and tariff data. Unpublished Reports. World trade organization, Geneva

Yang CC (2012) Assessing the moderating effect of innovationcapability on the relationship between logistics service capability and firm performance for ocean freight forwarders. International Journal of Logistics Research and Applications: A Leading Journal of Supply Chain Management 15(1):53-69

Yang YH, Hui YV, Leung LC, Chen G (2010) An analytic network process approach to the selection of logistics service providers for air cargo. Journal of the Operational Research Society 61(9):1365-1376

Zadeh LA (1965) Fuzzy sets. Information and Control 8:338-353

\section{Publisher's Note}

Springer Nature remains neutral with regard to jurisdictional claims in published maps and institutional affiliations.

\section{Submit your manuscript to a SpringerOpen ${ }^{\circ}$ journal and benefit from:}

- Convenient online submission

- Rigorous peer review

- Open access: articles freely available online

- High visibility within the field

- Retaining the copyright to your article

Submit your next manuscript at $\boldsymbol{s p r i n g e r o p e n . c o m ~}$ 